\title{
Phytochemical Analysis, Antifungal and Antioxidant Activity of Leaf and Fruit of Zizyphus xylopyrus (Retz.) Willd. (Rhamnaceae)
}

\author{
Raghavendra H.L ${ }^{1}$, Prashith Kekuda T. $\mathbf{R}^{2^{*}}$, Akarsh $\mathbf{S}^{2}$, Monica ${ }^{2}$ and Ashwini H.S $\mathbf{S}^{3}$ \\ ${ }^{1}$ School of Medicine, College of Medical and Health Sciences, Wollega University, \\ Post Box No: 395, Nekemte, Ethiopia \\ ${ }^{2}$ Department of Microbiology, S.R.N.M.N College of Applied Sciences, N.E.S campus, \\ Balraj Urs Road, Shivamogga-577201, Karnataka, India \\ ${ }^{3}$ Department of Microbiology, Sahyadri Science College (Autonomous), Shivamogga-577203, \\ Karnataka, India
}

\begin{tabular}{|c|c|}
\hline Abstract & Article Information \\
\hline \multirow{4}{*}{$\begin{array}{l}\text { In the present study, phytochemical screening, content of total phenolics, antifungal and } \\
\text { antioxidant activity of leaf and fruit extract of Zizyphus xylopyrus (Retz.) Willd. (Rhamnaceae) } \\
\text { was investigated in vitro. The leaf and fruit extracts were obtained by maceration process } \\
\text { using methanol as solvent. The extracts were screened for phytochemicals by standard tests. } \\
\text { Flavonoids, saponins, terpenoids, tannins and phenols were found in both extracts. Antifungal } \\
\text { activity of extracts was evaluated by poisoned food technique. Leaf extract suppressed the } \\
\text { growth of test fungi to high extent when compared to fruit extract. Antioxidant activity was } \\
\text { determined by DPPH radical scavenging, ABTS radical scavenging and Ferric reducing } \\
\text { assays. Both extracts exhibited radical scavenging and ferric reducing activity in dose } \\
\text { dependent manner with marked activity exhibited by leaf extract. Folin-Ciocalteau reagent } \\
\text { method was employed to estimate total phenolic content of extracts. Phenolic content was } \\
\text { slightly higher in leaf extract. A positive correlation was observed between phenolic content } \\
\text { and antioxidant activity. The plant can be used against phytopathogenic fungi and to prevent } \\
\text { and control oxidative damage. Further studies are to be carried out to isolate active principles } \\
\text { from the plant and to determine their bioactivities. } \\
\text { Copyright@2015 STAR Journal, Wollega University. All Rights Reserved. }\end{array}$} & $\begin{array}{ll}\text { ceived } & : 18 \\
\text { vised } & : 20 \\
\text { cepted }: & 22\end{array}$ \\
\hline & henolic content \\
\hline & $\begin{array}{l}\text { espondin } \\
\text { ith Keku }\end{array}$ \\
\hline & \\
\hline
\end{tabular}

\section{INTRODUCTION}

Plants play an important role for the existence and civilization of individuals since prehistoric period. Humans depend on plants for various needs such as medicine, food, spices, fodder, fuel, timber, resin, tannin and dyes (Nandini and Shiddamallayya, 2015). Plants are essential components of ethnomedicine and their use can be rightly called as ethnobotanic medicine. Throughout the world, whole plants or various parts of the plants are used traditionally for treatment of several ailments. The use of herbal medicine is most common in developing and under-developing countries. It is estimated that $80 \%$ of world's population rely on traditional medicine for primary health care needs. The dependence of people on herbal medicine is cost effectiveness, health benefits, acceptability and most importantly the accessibility. Plants are extensively used in various systems of medicine such as Ayurveda, Sidda and Unani. The therapeutic potential of plants lies in chemical components called phytochemicals that are present in plants. The most important of them are polyphenolic compounds including flavonoids, alkaloids, glycosides, saponins and terpenoids. These phytochemical are shown to exhibit bioactivities such as antimicrobial, antioxidant, antitumor and several other pharmacological activities. Plants provide lead compounds for developing new drugs. Plantderived drugs such as morphine, vinblastine, vincristine, quinine, digoxin, digitoxin, reserpine, taxol and artemisinin have made significant contributions in the field of medicine. Interest in medicinal plants has increased due to various drawbacks that are associated with modern medicine (Fabricant and Farnsworth, 2001; Yineger et al., 2008; Pushpangadan and George, 2010; Kingston, 2011; Mishra et al., 2012; Kulkarni et al., 2014; Ghosh et al., 2014; Alhakmani et al., 2014; Kumar and Shiddamallayya, 2016).

Ziziphus xylopyrus (Retz.) Willd. (Synonym Rhamnus xylopyrus Retz.) is a small tree or straggling shrub armed with spines belonging to the family Rhamnaceae. The plant is distributed in India, Pakistan, China and Sri Lanka. Bark is thin and young branches are tomentose. Leaves are simple, up to $6 \times 4.5 \mathrm{~cm}$, thin, alternate, elliptic or suborbicular, obtuse at apex. Flowers are in axillary cymes. Fruit is a drupe, $1.5-2.5 \mathrm{~cm}$ across and globose (Yoganarasimhan et al., 1981; Modi et al., 2014). Various chemical compounds such as quercetin, quercitrin, 
Raghavendra et al.,

vitamin $\mathrm{C}$, carotene, reducing sugars, sterol, fatty acids, kempferol, rutin, xylopyrine, lupeol and betulinic acid are found in different parts of the plant (Modi et al., 2014). The plant is used as wild edible and in fold medicine by various tribal communities. Bark and fruits are employed in making black dye for leather. Various parts of the plant is used in Ayurvedic and traditional medicine for the treatment of several ailments such as obesity, diabetes, snake bite, fever, diarrhoea, insomnia and digestive disorders (Yoganarasimhan et al., 1981; Arinathan et al., 2007; Reddy et al., 2009; Jain et al., 2010; Kulkarni and Adwait, 2011; Modi et al., 2014; Kumar and Shiddamallayya, 2016). Z. xylopyrus is shown to exhibit several bioactivities such as antimicrobial (Sameera and Mandakini, 2015), antidiarrhoeal (Singhal and SenthilKumar, 2011), antiulcer (Sharma et al., 2013), antioxidant (Sharma et al., 2013), analgesic (Mishra et al., 2012), anti-inflammatory (Mishra et al., 2012), wound healing (Jain et al., 2015), anti-depressant (Sharma et al., 2009) and antisteroidogenic effect (Dhanapal et al., 2012). In the present study, we screened methanolic extract of leaf and fruit of $Z$. xylopyrus for phytochemicals and determined antifungal and antioxidant activity of leaf and fruit extracts.

\section{MATERIALS AND METHODS}

\section{Collection and Identification of Plant}

The plant materials were collected during January 2015 in and around Sagara, Shivamogga district, Karnataka. The plant was identified by referring flora (Yoganarasimhan et al., 1981).

\section{Extraction of Leaf and Fruit}

The leaves and fruits were separated from the plant materials, washed well using clean water, dried under shade and powdered. Extraction was carried out by maceration process where known quantity of the powdered plant materials $(10 \mathrm{~g})$ was immersed in $100 \mathrm{ml}$ of methanol in clean conical flasks. With occasional stirrings, the flasks were left at room temperature for 48 hours followed by filtering the contents of flasks through muslin cloth followed by Whatmann No. 1. The filtrates were evaporated to dryness at $40^{\circ} \mathrm{C}$ to get extracts (Kekuda et al., 2015).

\section{Phytochemical Analysis of Leaf and Fruit Extracts}

The extracts were screened for detection of phytochemicals namely alkaloids, tannins, flavonoids, steroids, glycosides, saponins, terpenoids and phenols were detected by standard phytochemical tests (Bhandary et al., 2012; Mir et al., 2013; Yusuf et al., 2014).

\section{Antifungal Activity of Leaf and Fruit Extracts}

The antifungal effect of leaf and fruit extracts of $Z$. xylopyrus was determined by Poisoned food technique. Test fungi were inoculated aseptically at the centre of control (without extract) and poisoned $(0.5 \mathrm{mg}$ extract $/ \mathrm{ml}$ of medium) potato dextrose agar plates followed by incubating the plates at $28 \pm 2^{\circ} \mathrm{C}$ for 72 hours. The diameter of fungal colonies in mutual perpendicular directions was measured using a ruler. Antifungal activity, in terms of inhibition of mycelial growth of test fungi, was determined using the formula:

Inhibition of mycelial growth $(\%)=(\mathrm{C}-\mathrm{T} / \mathrm{C}) \times 100$

where $\mathrm{C}$ and $\mathrm{T}$ denotes the diameter of colonies in control and poisoned plates respectively (Kekuda et al., 2015).
Sci. Technol. Arts Res. J., Oct-Dec 2015, 4(4): 83-88

\section{Antioxidant Activity of Leaf and Fruit Extracts \\ DPPH Radical Scavenging Activity}

Leaf and fruit extracts and ascorbic acid (6.25$200 \mu \mathrm{g} / \mathrm{ml})$ and DPPH (1,1-diphenyl-2-picrylhydrazyl) radical solution $(0.004 \%)$ were prepared in methanol. $1 \mathrm{ml}$ of different concentrations extracts was mixed with $3 \mathrm{ml}$ of DPPH radical solution in clean and labeled tubes. The tubes were kept in dark for 30 minutes at room temperature. The absorbance of each tube was measured in spectrophotometer at $517 \mathrm{~nm}$. Methanol replacing the extract/ascorbic acid served as control. Scavenging activity (\%) of each concentration of extracts/ascorbic acid was calculated using the formula:

Scavenging of DPPH radicals $(\%)=(C-T / C) \times 100$

where ' $C$ ' and ' $T$ ' denotes to absorbance of DPPH control and absorbance of DPPH in presence of extract/ascorbic acid. The $\mathrm{IC}_{50}$ (Inhibitory Concentration) value was calculated which indicates the concentration of extract/ascorbic acid required to scavenge $50 \%$ of free radicals (Kekuda et al., 2015).

\section{ABTS Radical Scavenging Activity}

Different concentrations of extracts and ascorbic acid $(6.25-200 \mu \mathrm{g} / \mathrm{ml})$ were prepared in methanol. $1 \mathrm{ml}$ of different concentrations of extracts/ascorbic acid was mixed with $3 \mathrm{ml}$ of ABTS (2,2-azinobis 3ethylbenzothiazoline 6-sulfonate) radical solution (previously generated by mixing ABTS salt and potassium persulfate) in clean and labeled tubes. The tubes were left for 30 minutes at room temperature and the absorbance was measured in a spectrophotometer at $730 \mathrm{~nm}$. The radical scavenging activity of extracts/ascorbic acid was calculated using the formula:

$$
\text { Scavenging activity }(\%)=(C-T / C) \times 100
$$

where ' $C$ ' denotes the absorbance of the ABTS solution without extract/ ascorbic acid and ' $T$ ' represents the absorbance of ABTS solution in the presence of extract/ascorbic acid. The $\mathrm{IC}_{50}$ value was calculated and it denotes the concentration of extract/ascorbic acid required to scavenge $50 \%$ of the radicals (Kekuda et al., 2015).

\section{Ferric Reducing Activity of Extracts}

The reducing activity of leaf and fruit extracts of $Z$. xylopyrus was determined by Ferric reducing assay (Kekuda et al., 2014). In clean and labeled tubes, different concentrations of extracts/ascorbic acid $(6.25-200 \mu \mathrm{g} / \mathrm{ml})$ in $1 \mathrm{ml}$ of methanol were mixed with $2.5 \mathrm{ml}$ of phosphate buffer $(\mathrm{pH} 6.6)$ and $2.5 \mathrm{ml}$ of potassium ferricyanide (1\%). The tubes were incubated at $50^{\circ} \mathrm{C}$ for 20 minutes and cooled. To each tube, $2.5 \mathrm{ml}$ of trichloroacetic acid $(10 \%)$ followed by $0.5 \mathrm{ml}$ of ferric chloride $(0.1 \%)$ was added. The tubes were left at room temperature for 10 minutes and the absorbance was measured at $700 \mathrm{~nm}$ in spectrophotometer. An increase in the absorbance with increase in concentration of extracts/ascorbic acid indicates reducing power.

\section{Total Phenolic Content of Extracts}

To estimate the total phenolic content of leaf and fruit extracts of $Z$. xylopyrus, Folin-Ciocalteau reagent method was used. A dilute concentration of each extract $(0.5 \mathrm{ml})$ was mixed with $0.5 \mathrm{ml}$ of FC reagent $(1: 10)$ and $2 \mathrm{ml}$ of sodium carbonate $(2 \%)$ and the tubes were incubated at room temperature for 30 minutes. The absorbance of each tube was measured at $765 \mathrm{~nm}$ in spectrophotometer. 
Raghavendra et al.,

A standard curve was constructed using different concentrations of Gallic acid (standard, $0-1000 \mu \mathrm{g} / \mathrm{ml}$ ) and the total phenolic content was represented as $\mathrm{mg}$ Gallic Acid Equivalents (Kekuda et al., 2015).

\section{RESULT AND DISCUSSION}

\section{Qualitative Phytochemical Analysis of Leaf and Fruit} extracts

The medicinal properties of plants are due to the presence of secondary metabolites such as flavonoids, tannins, alkaloids, glycosides, alkaloids, saponins and terpenoids. These chemicals are called phytochemicals. Phytochemistry deals with the study of these phytochemicals. These phytochemicals have profound physiological effects on the health. Therefore, the detection of these chemicals in medicinal plants is important so as to relate the possible therapeutic role with these phytochemicals (Cowan, 1999; Bhandary et al., 2012; Mir et al., 2013; Yusuf et al., 2014). In the present study, we chose methanol as extraction solvent. Among various solvents used for extraction of phytochemicals, methanol seems to be the best solvent for extract as it has been shown that methanol can dissolve many phytochemicals including polyphenolic compounds present in the plants (Cowan, 1999; Gurjar et al., 2012; Naz et al., 2013; lloki-Assanga et al., 2015). In the present study, maceration process using methanol solvent was performed to obtain extract of leaf and fruit of $Z$. xylopyrus. The phytochemicals that were detected in extracts are shown in Table 1. Flavonoids, saponins, terpenoids, tannins and phenols were detected in both leaf and fruit extracts. Alkaloids were detected in leaf extract only. Glycosides and steroids were not detected in both extracts.

Table 1: Phytoconstituents in leaf and fruit extracts

\begin{tabular}{lcc}
\hline Phytochemical & Leaf & Fruit \\
\hline Alkaloids & + & - \\
Flavonoids & + & + \\
Saponins & + & + \\
Terpenoids & + & + \\
Glycosides & - & - \\
Tannins & + & + \\
Phenols & + & + \\
Steroids & - & -
\end{tabular}

\section{Antifungal Activity of Leaf and Fruit Extracts}

Humans depend on plants for various needs such as food, medicine, timber and dyes. Due to increase in population, there is an increase in demand for food. Production of crops is constantly threatened by various factors among which pests are one of the important factors. Among various pests which affect crop production, fungi are considered as dominant group of pests as they cause a huge number of disease in agricultural crops. In severe cases, fungal diseases results in $>50 \%$ of crop loss. One of the widely used approaches to control fungal diseases of crops is the usage of chemical fungicides. These chemicals affect the fungal pathogens and reduce disease incidence. However, the usage of these chemical agents is accompanied with some drawbacks. It results in residual
Sci. Technol. Arts Res. J., Oct-Dec 2015, 4(4): 83-88

problem for environment where soil and underground water contamination can possibly occur. Besides, several fungal pathogens have developed resistance against some fungicides. Use of botanicals to control plant diseases seems to be one of the best alternatives for chemical control. Various studies which utilized plants and their components have highlighted the potential of plants to inhibit several fungal pathogens (Gomathi and Kannabiran, 2000; Nduagu et al., 2008; Johnny et al., 2011; Bajpai and Kang, 2012; Ajith et al., 2012; Suprapta, 2012; Bahraminejad et al., 2012; Shweta et al., 2015). In the present study, we screened the antifungal activity of leaf and fruit extract of $Z$. xylopyrus by Poisoned food technique which is one of the widely used methods to evaluate antifungal activity of various kinds of samples including plant extracts. The mycelial growth of test fungi was affected by the extract as evidenced by reduction in colony diameter of test fungi in poisoned plates (when compared with control). Among extracts, leaf extract displayed high inhibitory activity when compared to fruit extract. $A$. flavus was susceptible to high extent than $A$. alternata to extracts.

Table 2: Antifungal activity of leaf and fruit extract

\begin{tabular}{lccc}
\hline \multirow{2}{*}{ Test fungi } & \multicolumn{3}{c}{ Colony diameter in cm (\% inhibition) } \\
\cline { 2 - 4 } & Control & Leaf extract & Fruit extract \\
\hline A. alternata & 2.8 & $2.0(28.57)$ & $2.2(21.42)$ \\
A. flavus & 3.4 & $2.3(32.35)$ & $2.4(29.41)$ \\
\hline
\end{tabular}

DPPH Radical Scavenging Activity of Leaf and Fruit Extracts

Out of various in vitro radical scavenging assays, DPPH assay is simple, rapid, inexpensive and widely used assay. This method uses a stable free radical DPPH and was developed by Blois (1958) in order to determine the antioxidant potential. The assay is based on the measurement of the scavenging capacity of antioxidants. DPPH is a stable, organic, nitrogen centred free radical having an absorption maximum at $517 \mathrm{~nm}$ in alcoholic solution. In DPPH, the odd electron of nitrogen atom is reduced when it receives a hydrogen atom from antioxidants leading to the formation of corresponding hydrazine (absorption decreases as the electron pairs off). The decolorization is stoichiometric with respect to the number of electrons taken up. DPPH assay is widely used method to measure the antioxidant capacity of plant extracts (Blois, 1958; Wangcharoen and Morasuk, 2007; Krishna and Nair, 2010; Aiyegoro and Okoh, 2010; Kekuda et al., 2015). In the present study, we determined the effect of leaf and fruit extracts of Z. xylopyrus to scavenge radicals by DPPH assay. Fading away of color of DPPH radical solution was monitored in presence of varying concentrations of extracts and standard at $517 \mathrm{~nm}$. Extracts and ascorbic acid scavenged DPPH radicals in a concentration dependent manner (Figure 1). Among extracts, leaf extract exhibited stronger scavenging potential $\left(\mathrm{IC}_{50} 31.73\right.$ value $\left.\mu \mathrm{g} / \mathrm{ml}\right)$ when compared to fruit extract $\left(\mathrm{IC}_{50}\right.$ value $\left.36.79 \mu \mathrm{g} / \mathrm{ml}\right)$. Ascorbic acid exhibited marked scavenging of DPPH radicals $\left(\mathrm{IC}_{50}\right.$ value $6.17 \mu \mathrm{g} / \mathrm{ml}$ ). From the results, it is certain that the extracts of $Z$. xylopyrus possess hydrogen donating property and hence the extracts can act as potent free radical scavengers. 
Raghavendra et al.,

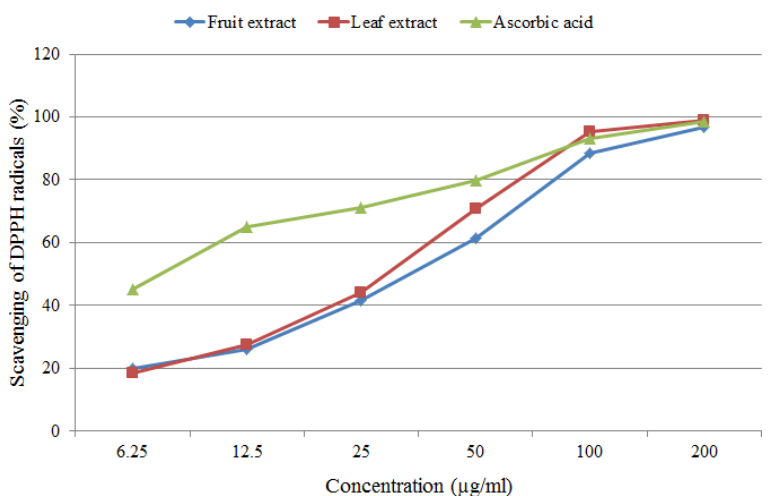

Figure 1: DPPH radical scavenging activity of leaf and fruit extracts

\section{ABTS Radical Scavenging Activity of Leaf and Fruit Extracts}

The assay involving scavenging of ABTS radical cation is another commonly used in vitro radical scavenging assay. Unlike DPPH method, scavenging of ABTS radical cation requires generation of radical cation. This can be done by reacting ABTS stock solution $(7 \mathrm{mM})$ with postassium persulphate $(2.45 \mathrm{mM})$ and incubating the mixture in dark condition at room temperature for 12-16 hours. The radical solution was diluted with water to an absorbance of 0.70 at $734 \mathrm{~nm}$. Scavenging of ABTS radical cations is useful in determining the antioxidant capacity of both lipophilic and hydrophilic antioxidants. This method has been used to evaluate radical scavenging potential of variety of samples including plant extracts. A compound having the property of donation of electrons will reduce the blue-green ABTS radical solution to colorless neutral form which is indicated by the suppression of characteristic long wavelength absorption spectrum of radical (Re et al., 1999; Wangcharoen and Morasuk, 2007; Camacho-Luis et al., 2008; Krishna and Nair, 2010; Aiyegoro and Okoh, 2010; Kekuda et al., 2015). In the present study, we evaluated the potential of leaf and fruit extracts of $Z$. xylopyrus to scavenge ABTS radical cations and the result is shown in Figure 2. Both extracts were able to scavenge ABTS radicals in a concentration dependent manner. Leaf extract displayed marked scavenging activity $\left(\mathrm{IC}_{50}\right.$ value $\left.4.61 \mu \mathrm{g} / \mathrm{ml}\right)$ when compared to fruit extract $\left(\mathrm{IC}_{50}\right.$ value $\left.8.37 \mu \mathrm{g} / \mathrm{ml}\right)$. Ascorbic acid exhibited stronger scavenging activity $\left(\mathrm{IC}_{50}\right.$ value $3.05 \mu \mathrm{g} / \mathrm{ml}$ ) when compared to extracts. From the results, it is confirmed that the extracts of $Z$. xylopyrus possess electron donating property and hence the extracts can act as potent free radical scavengers.

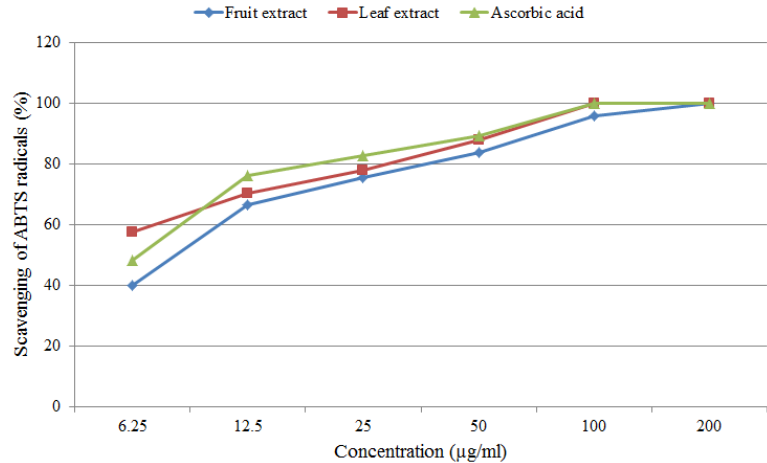

Figure 2: ABTS radical scavenging activity of leaf and fruit extracts
Sci. Technol. Arts Res. J., Oct-Dec 2015, 4(4): 83-88

\section{Ferric Reducing Activity of Leaf and Fruit Extracts}

Reduction of Fe (III) is often used as an indicator of electron donating property of samples and is an important mechanism of antioxidant action (Ebrahimzadeh et al., 2010). The reducing ability is an indication of total capacity of host to withstand adverse effect of stress induced by free radicals. Reducing ability reflects the electron donating property which is associated with antioxidant activity. The presence of reductants (antioxidants) in extracts would results in the reduction of ferric complex to ferrous form and this can be determined by the direct reduction of $\mathrm{Fe}\left[(\mathrm{CN})_{6}\right]_{3}$ to $\mathrm{Fe}\left[(\mathrm{CN})_{6}\right]_{2}$. Upon addition of free $\mathrm{Fe}^{3+}$ to the reduced product, formation of the intense Perl's Prussian blue complex, $\mathrm{Fe}_{4}\left[\mathrm{Fe}(\mathrm{CN})_{6}\right]_{3}$, having a strong absorbance at $700 \mathrm{~nm}$ is observed. An increase in absorbance with an increase in concentration of compound indicates reducing capacity of compound (Ebrahimzadeh et al., 2010; Gulcin et al., 2011; Meir et al., 1995; Chung et al., 2006; Aiyegoro and Okoh, 2010; Kekuda et al., 2011). In the present study, we screened the leaf and fruit extracts of $Z$. xylopyrus for ferric reducing activity and the result is shown in Figure 3 . On increasing the concentration of extract, a corresponding increase in the absorbance of reaction mixtures was observed which indicated reducing power of the extracts. Among extracts, marked reducing potential was observed in case of leaf extract. However, ascorbic acid displayed higher reducing potential. It is evident from this study that the extracts of $Z$. xylopyrus exhibit reductive ability and hence, the extracts could serve as electron donors, terminating the radical chain reactions (Chung et al., 2006).

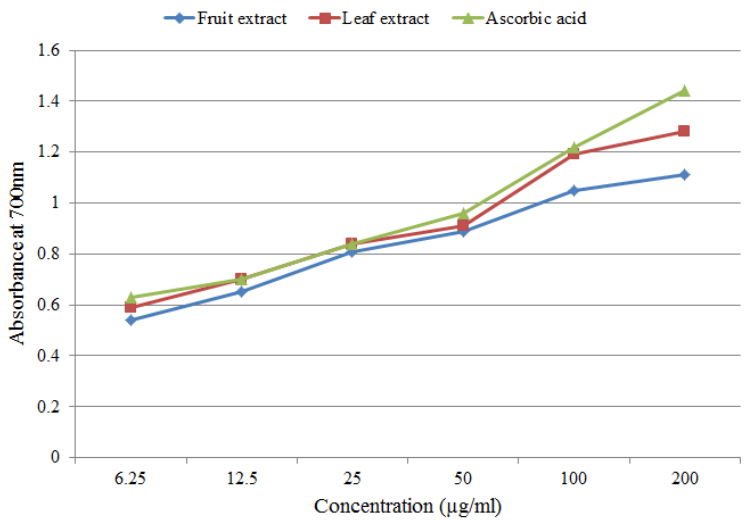

Figure 3: Ferric reducing activity of leaf and fruit extracts

\section{Total Phenolic Content of Leaf and Fruit Extracts}

In recent years, there has been immense interest in antioxidants from natural origin especially from plants. Polyphenols including flavonoids appears to be promising antioxidant chemical species in plants. The presence of phenolic compounds in plants is related to several health benefits including antioxidant activity. FCR method is a simple, oldest and rapid method used for estimating the total phenolic content in variety of samples including plant extracts. Phenolic compounds react with FCR under basic conditions resulting in the formation of a blue colored complex with absorption maxima near $750 \mathrm{~nm}$ (Boonyuen et al., 2009; Ebrahimzadeh et al., 2010; Aiyegoro and Okoh, 2010; Kekuda et al., 2015). In the present study, we estimated the phenolic content of leaf and fruit extracts by FCR method. There was no much variation in the phenolic content of both the extracts. Leaf extract was found to contain slightly high phenolic content $(68.16 \mathrm{mg}$ $\mathrm{GAE} / \mathrm{g}$ ) when compared to fruit extract (62.62mg GAE/g). 
Raghavendra et al.,

In this study, a positive correlation between antioxidant activity and phenolic content was observed i.e., leaf extract exhibited higher antioxidant activity when compared to fruit extract.

\section{CONCLUSIONS}

Leaf and fruit extract of $Z$. xylopyrus displayed antifungal and antioxidant activity. The observed bioactivities could be attributed to the presence of phytochemicals in the extracts. Bioactivities shown were higher in case of leaf extract when compared to fruit extract. The plant can be used against phytopathogenic fungi and oxidative damage. Further studies are to be carried out to isolate and characterize active components from extracts and to determine their biological activities.

\section{Conflict of Interest}

Conflict of interest none declared.

\section{Acknowledgements}

Authors thank Principal, S.R.N.M.N College of Applied Sciences and N.E.S, Shivamogga for the facilities and moral encouragement provided. Authors also thank Prof. D. Rudrappa, Dept. of Botany, S.R.N.M.N College of Applied Sciences, Shivamogga, Karnataka for helping in identification of plant.

\section{REFERENCES}

Aiyegoro, O.A. and Okoh, A.I. (2010). Preliminary phytochemical screening and in vitro antioxidant activities of the aqueous extract of Helichrysum longifolium DC. BMC Complementary and Alternative Medicine 10: 21.

Ajith, P.S., Lakshmesha, K.K., Murthy, M. and Lakshmidevi, N. (2012). Botanicals for control of anthracnose of bell peppers. The Journal of Plant Protection Sciences 4(1): 13-19.

Alhakmani, F., Khan, S.A., Ahmad, A. (2014). Determination of total phenol, in-vitro antioxidant and anti-inflammatory activity of seeds and fruits of Zizyphus spina-christi grown in Oman. Asian Pacific Journal of Tropical Biomedicine 4(S2): S656-S660.

Arinathan, V., Mohan, V.R., De Britto, J.A. and Murugan, C. (2007). Wild edibles used by Palliyars of the Western Ghats, Tamil Nadu. Indian Journal of Traditional Knowledge 6(1): 163-168.

Bahraminejad, S., Abbasi, S., Maassoumi, S.M. and Tabein, S. (2012). Evaluation of inhibitory effects of extracts of plants from western Iran against Phytophthora drechsleri. Australian Journal of Crop Science 6(2): 255-260.

Bajpai, V.K. and Kang, S.C. (2012). In vitro and in vivo inhibition of plant pathogenic fungi by essential oil and extracts of Magnolia liliflora Desr. Journal of Agricultural Science and Technology 14: 845-856.

Blois, M.S. (1958). Antioxidant determinations by the use of a stable free radical. Nature 181: 1199-1200.

Boonyuen, C., Wangkarn, S., Suntornwat, O. and Chaisuksant, R. (2009). Antioxidant capacity and phenolic content of Mimusops elengi fruit extract. Kasetsart Journal (Natural Science) 43: 21-27.

Camacho-Luis, A., Gayosso-De-Lucio, J.A., Torres-Valencia, J.M., Muñoz-Sánchez, J.L., Alarcón-Hernández, E., López, R. and Barrón, B.L. (2008). Antioxidant constituents of Geranium bellum Rose. Journal of Mexican Chemical Society 52(2): 103-107.
Sci. Technol. Arts Res. J., Oct-Dec 2015, 4(4): 83-88

Chung, Y., Chien, C., Teng, K. and Chou, S. (2006). Antioxidative and mutagenic properties of Zanthoxylum ailanthoides Sieb \& zucc. Food Chemistry 97: 418-425.

Cowan, M.M. (1999). Plant products as antimicrobial agents Clinical Microbiology Reviews 12(4):564-582.

Dhanapal, R., Ratna, J.V., Gupta, M. and Sarathchandiran, I. (2012). Ovarian antisteroidogenic effect of three ethnomedicinal plants in prepubertal female mice. International Journal of Biological and Pharmaceutical Research 3(1): 30-36.

Ebrahimzadeh, M.A., Nabavi, S.M., Nabavi, S.F. and Eslami, B. (2010). Antioxidant activity of the bulb and aerial parts of Ornithogalum sintenisii L (Liliaceae) at flowering stage. Tropical Journal of Pharmaceutical Research 9(2): 141148.

Fabricant, D.S. and Farnsworth, N.R. (2001). The value of plants used in traditional medicine for drug discovery. Environmental Health Perspectives 109: 69-75.

Ghosh, S.K., Guchhait, S.K. and Santra, S. (2014). Decay of traditional ecological knowledge and ethno medicine: A study in Joypur jungle mahal, Bankura district, West Bengal. IOSR Journal of Humanities and Social Science 19(3): 74-80.

Gomathi V. and Kannabiran, B. (2000). Inhibitory effects of leaf extracts of some plants on the anthracnose fungi infecting Capsicum annum. Indian Phytopathology 53(3): 305-308.

Gulcin, I., Topal, F., Sarikaya, S.B.O., Bursal, E., Bilsel, G. and Goren, A.C. (2011). Polyphenol contents and antioxidant properties of Medlar (Mespilus germanica L.). Records of Natural Products 5(3): 158-175.

Gurjar, M.S., Ali, S., Akhtar, M. and Singh, K.S. (2012) Efficacy of plant extracts in plant disease management. Agricultural Sciences 3(3): 425-433.

lloki-Assanga, S.B., Lewis-Luján, L.M., Lara-Espinoza, C.L., Gil-Salido, A.A., Fernandez-Angulo, D., Rubio-Pino, J.L. and Haines, D.D. (2015). Solvent effects on phytochemical constituent profiles and antioxidant activities, using four different extraction formulations for analysis of Bucida buceras L. and Phoradendron californicum. BMC Research Notes 8: 396.

Jain, A.K., Vairale, M.G. and Singh, R. (2010). Folklore claims on some medicinal plants used by Bheel tribe of Guna district Madhya Pradesh. Indian Journal of Traditional Knowledge 9(1): 105-107.

Jain, R.K., Tiwari, M., Rajoriya, V., Sharma, A. and Kashaw, V. (2015). Evaluation of ethanolic extract of Zizyphus xylopyrus Willd on wound healing activity in rats. European Journal of Pharmaceutical and Medical Research 2(7): 304-309.

Johnny, L., Yusuf, U.K. and Nulit, R. (2011). Antifungal activity of selected plant leaves crude extracts against a pepper anthracnose fungus, Colletotrichum capsici (Sydow) butler and bisby (Ascomycota: Phyllachorales). African Journal of Biotechnology 10(20): 4157-4165.

Kekuda, P.T.R., Akarsh, S., Darshini, S.M., Prafulla, D. and Raghavendra, H.L. (2015). Antiradical and antimicrobial activity of Atylosia lineata Wt. and Arn. Science, Technology and Arts Research Journal 4(3): 180-183.

Kekuda, P.T.R., Raghavendra, H.L., Mallikarjun, N., Swathi, D., Suchitha, Y., Kumar, A.H.S. and Vinayaka, K.S. (2014). Elemental analysis and biological activities of Chrysophyllum roxburghii G. Don (Sapotaceae) leaves. 
Raghavendra et al.,

Science, Technology and Arts Research Journal 3(1): 1420.

Kekuda, P.T.R., Vinayaka, K.S., Swathi, D., Suchitha, Y., Venugopal, T.M. and Mallikarjun, N. (2011). Mineral composition, total phenol content and antioxidant activity of a macrolichen Everniastrum cirrhatum (Fr.) Hale (Parmeliaceae). E-Journal of Chemistry 8(4): 1886-1894.

Kingston, D.G.I. (2011). Modern natural products drug discovery and its relevance to biodiversity conservationt. Journal of Natural Products 74(3): 496-511.

Krishna, M.S. and Nair, J.A. (2010). Antibacterial, cytotoxic and antioxidant potential of different extracts from leaf, bark and wood of Tectona grandis. International Journal of Pharmaceutical Sciences and Drug Research 2(2): 155-158.

Kulkarni, C.G. and Adwait, D. (2011). Folk therapies of Katkaris from Maharashtra. Indian Journal of Traditional Knowledge 10(3): 554-558.

Kulkarni, K.M., Patil, L.S., Khanvilkar, V.V. and Kadam, V.J. (2014). Fingerprinting techniques in herbal standardization. Indo American Journal of Pharmaceutical Research 4(2): 1049-1062.

Kumar, P.G.M. and Shiddamallayya, N. (2016). Survey of wild medicinal plants of Hassan district, Karnataka. Journal of Medicinal Plants Studies 4(1): 91-102.

Meir, S., Kanner, J., Akiri, B. and Hadas, S.P. (1995). Determination and involvement of aqueous reducing compounds in oxidative defense systems of various senescing Leaves. Journal of Agricultural and Food Chemistry 43:1813-1817.

Mir, A.M., Sawhney, S.S. and Jassal, M.M.S. (2013). Qualitative and quantitative analysis of phytochemicals of Taraxacum officinale. Wudpecker Journal of Pharmacy and Pharmocology 2(1): 1-5.

Mishra, U.S., Murthy, P.N. and Parida, S.K. (2012). Analgesic and anti-inflammatory activities of Indian medicinal plant Ziziphus xylopyrus stem barks in experimental animal models. Elixir Pharmacy 44: 7265-7270.

Modi, A., Jain, S. and Kumar, V. (2014). Zizyphus xylopyrus (Retz.) Willd : a review of its folkloric, phytochemical and pharmacological perspectives. Asian Pacific Journal of Tropical Disease 4(S1): S1-S6.

Nandini, N. and Shiddamallayya, N. (2015). Potential minor forest products wealth of old Mysore district, Karnataka, India. International Journal of Current Innovation Research 1(5): 109-115.

Naz, F., Qamarunnisa, S., Shinwari, Z.K., Azhar, A. and Ali, S.I. (2013). Phytochemical investigations of Tamarix indica Willd. And Tamarix passernioides Del. ex Desv. leaves from Pakistan. Pakistan Journal of Botany 45(5): 1503-1507.
Sci. Technol. Arts Res. J., Oct-Dec 2015, 4(4): 83-88

Nduagu, C., Ekefan, E.J. and Nwankiti, A.O. (2008). Effect of some crude plant extracts on growth of Colletotrichum capsici (Synd) Butler \& Bisby, causal agent of pepper anthracnose. Journal of Applied Biosciences 6(2): 184190.

Pushpangadan, P. and George, V. (2010). Ethnomedicinal practices of rural and tribal populations of India with special reference to the mother and childcare. Indian Journal of Traditional Knowledge 9(1): 9-17.

Re, R., Pellegrini, N., Proteggente, A., Pannala, A., Yang, M. and Rice-Evans, C. (1999). Antioxidant activity applying an improved ABTS radical cation decolorization assay. Free Radical Biology and Medicine 26(9/10): 1231-1237.

Reddy, S.C., Reddy, K.N., Murthy, E.N. and Raju, V.S (2009). Traditional medicinal plants in Seshachalam hills, Andhra Pradesh, India. Journal of Medicinal Plants Research 3(5): 408-412.

Sameera, N.S. and Mandakini, B.P. (2015). Investigations into the antibacterial activity of Ziziphus mauritiana Lam. and Ziziphus xylopyra (Retz.) Willd. International Food Research Journal 22(2): 849-853.

Sharma, V., Patel, S., Chauhan, N.S., Lodhi, S. and Singhai, A. (2013). A study of antioxidant and antiulcer activity of Zizyphus xylopyrus. Spatula DD 3(4):167-174.

Sharma, V.K., Chauhan, N.S., Lodhi, S. and Singhai, A.K. (2009). Anti-depressant activity of Zizyphus xylopyrus. International Journal of Phytomedicine 1: 12-17.

Shweta, S.D., Sudeshna, C.S., Rashmi, K., Vrushala, P.S. and Kekuda, P.T.R. (2015). Antifungal efficacy of some epiphytic orchids of Karnataka, India. Scholars Journal of Agriculture and Veterinary Sciences 2(3B): 266-269.

Singhal, U. and SenthilKumar, K. (2011). Antidiarrhoeal activity of fruit extract of Ziziphus xylopyrus (Retz.)Willd in rats. International Journal of Pharmaceutical Erudition 1(2): 57-61.

Suprapta, D.N. (2012). Potential of microbial antagonists as biocontrol agents against plant fungal pathogens. Journal of ISSAAS 18(2): 1-8.

Wangcharoen, W. and Morasuk, W. (2007). Antioxidant capacity and phenolic content of some Thai culinary plants. Maejo International Journal of Science and Technology 1(2): 100-106.

Yineger, H., Yewhalaw, D. and Teketay, D. (2008). Ethnomedicinal plant knowledge and practice of the Oromo ethnic group in southwestern Ethiopia. Journal of Ethnobiology and Ethnomedicine 4: 11.

Yoganarasimhan, S.N., Subramanyam, K. and Razi, B.A. (1981). Flora of Chikmagalur district. International Book Distributors, Dehra Dun. Pp 77-78.

Yusuf, A. Z., Zakir, A., Shemau, Z., Abdullahi, M. and Halima, S. A. (2014). Phytochemical analysis of the methanol leaves extract of Paullinia pinnata Linn. Journal of Pharmacognosy and Phytotherapy 6(2): 10-16. 